\title{
The Undemocratic Future of 21st Century Liberal Democracy
}

\author{
Prof. Fernando Lopez-Alves \\ University of California, USA \\ Global and International Studies, \\ University of Salamanca, Spain
}

\section{Abstract}

What is the future of liberal democracy? Is the "liberal" ingredient of $21^{\text {st }}$ century democracy compatible with its "demos"? Are developed democracies more equalitarian and less stratified than other regimes? Or are present day democracies evolving into something different that needs a new definition?

By the early 1990s liberal democracy appeared to have become the dominant system at a global scale. The hope of citizens, scholars, and observers was that the stride toward broader democratization and inclusion would continue. It did, but as this paper argues, the forms adopted by democratic regimes, especially under the fourth industrial revolution, are not necessarily democratic. Rather, liberal democracies have created a new aristocracy that includes high tech monopolies, extremely skilled professionals, and a selected intelligentsia that from social media, conglomerates, and many times Hollywood, supports this new stratified version of the democratic polity. Family dynasties, clientele networks, and mechanisms of reward and punishment reminds us of the pseudo democracies of the late $19^{\text {th }}$ century.

Surely the dwindling middle class in developed democracies still have some consumer power based on credit. Global markets offer many more available consumer goods than in the past, creating the illusion that all is going well. Comparatively, however, democracies are doing worse. As this paper shows, $21^{\text {st }}$ century liberal democracies have concentrated wealth in fewer hands than in the recent past, have favored power centralization especially in the executive branch, have stimulated the formation of giant high-tech monopolies, and have generated more rigid forms of social stratification.

Liberal democracies, therefore, are weaking, in many cases as the logical consequence of the natural evolution of the liberal doctrine, and in most cases because of profound changes at the global scale. Citizens' confidence in their elected representatives has been in the decline for a long time. The increasing influence of populist nationalism is an indicator that confidence in traditional politicians continues to deteriorate. Democracy could not be democratic without the popular vote, but it has been precisely the popular vote that has empowered populist nationalist leaders, both from the right and the left. There is not very much that democracies can do about the coming to 
power via the ballot box of leaders who can rework the system in their favor and, in some cases, destroy it.

As the paper shows, changes in the international system of power have not been favorable to liberal democracies, adding to its burdens. They are no longer the optimal model of choice, especially in the less developed world. Finally, I claim that the broken promises of political elites that have traditionally provoked voters' apathy and loss of trust, have, In the $21^{\text {st }}$ century, created new unintended consequences. They have generated illusions of entitlement and deservingness that, especially young voters, have converted into a sort anti-democratic culture that cares less for the collective and much more for themselves.

Keywords: liberal democracy; globalization; United States; China; Fourth Industrial Revolution; populist nationalism.

\section{Introduction}

About 20 years ago I wrote a book focusing on less developed democracies, Societies with no Future, in which I argued that the nemesis of democracy in Latin America was lack of planning for the future. ${ }^{1}$ Electoral cycles driven by short term agendas or no agendas at all, prevented long time planning. Ignorance about the international system or convenient obliviousness as to its workings, political corruption, and irrational tax structures conspired to convince the citizenry that their societies had no future, no prospects. Their faith in democracy waned.

The most threatening enemy of democracy in those countries did not came from outside. Rather, democracy was undermined from within. At that time, military coups or external threats had virtually disappeared. Political elites, confident of their privilege position, became reluctant to leave office and used the very institutions of democracy to retain power. Prone to theatricals, strong entitlement, and indifference to the needs of their constituencies -except at electoral times - the political elite lost legitimacy, paving the way for populist nationalism (PN).

Citizens believed that they had lost control of their political systems. Their countries --as they expressed in interviews that I conducted from 2009 to in Argentina, Colombia, Ecuador, Uruguay, and Chile- "did not belong to them". ${ }^{2}$ A major winner of this situation was PN, which resurged with a vengeance in different countries. Populist leaders claimed to be outsiders and therefore closer to "the people" but they had been long connected to the political and the military establishment. This should sound familiar to present day Europeans and Americans. It is also a warning that should not

\footnotetext{
${ }^{1}$ Fernando Lopez-Alves, Societies with No Future (Sociedades sin Destino) Sudamericana Editors, Buenos Aires, 2000.

2 "Urban National Identity in Argentina, Colombia, and Uruguay: The Decline of the Nation State". Working Papers, University of CEMA, 2018, No 122.
} 
be taken lightly because to remain democratic democracies cannot avoid leaders who really do not believe in democracy gaining power through the ballot box.

More than twenty years ago, PN leaders from the left (or pseudo-left) as well as the right vowed to save their countries from corruption, malfeasance, and a dishonest political elite. Some of them, however, remain in power to this day, while others left office only after creating large clientele networks that brought them back to power more than once. The control of $40 \%$ of the vote emerged as the magic number that allowed populists to undermine democratic competition.

Political divisions at the top, irreconcilable quarrels at both the top and to bottom of the political scale, lack of long-term planning, and damaging vote seeking strategies depicts present day developed democracies. A combination of populism and nationalism that for many years characterized the less developed world has now consolidated in the US and the EU. PN has migrated from the periphery to the core of the global system. ${ }^{3}$

But this is only one of the many problems that 21st century democracies face. Especially in the US but also in the EU, under the fourth industrial revolution democracies have become less democratic and more stratified.

Several crucial questions need consideration. What is the future of liberal democracy? Is the "liberal" ingredient of $21^{\text {st }}$ century democracy compatible with its "demos"? Are developed democracies more equalitarian and less stratified than other regimes? Or are they evolving into something different that needs a new definition?

\section{A Fractured Polity}

"In the end, opposites are one and the same" Heraclitus of Ephesus, On Nature

Heraclitus statement resonates today more than ever. Both conservative right wing $\mathrm{PN}$ and leftists' versions preach something similar. Both want a new type of society not necessarily democratic, a stronger leadership, to ban the opposition from decision making, and selected groups of people representing the "real nation". They differ in terms of what kind of nation they want both mistrust liberal democracy and want to consolidate power and keep it. Populism appeals directly to the demo, to the people, and it has declared itself to be the representative of those who are excluded. Both conservative and leftist populists coincide on this point. They also share a similar strategy of confrontation with the traditional structure of the political system. Left-wing populists claim to be the protectors of the poor, and so do right wing ones.

Both forms of PN have developed extremist, intransigent attitudes that makes alliances and dialogue difficult. Even if their ultimate goal is not the total destruction of liberal 
democracy -- their main interest is to manipulate the democratic system rather than totally destroy it-- their militance and disregard for the collective can threaten its stability. Indeed, liberal democracies have developed a tendency to what Legutko has called the "totalitarian temptations" of free societies. ${ }^{4}$

In Central and Eastern European post-communist regimes, he argues, the traditional propensity to centralize power got along perfectly well with liberalism. Clearly, we see some of that today in the United States. Anti-communists who had fought against the Soviet imposed system were brushed aside, while communist managers retained their posts because they were "better managers". The point is that liberal democrats opposed no moral resistance to the dominance of the old nomenklatura. The lesson: liberalism can comfortably coexist with centralizing trends.

The dividing line between democracy and authoritarian forms of rule is not as clearly demarcated as one tends to think. In theory, this line is quite apparent, but not in practice. Democracies are fragile systems and at times the combination of the demos of democracy with liberalism is conflictive. Democracies represent a unique historical outcome in the history of humanity, a rare combination of individual rights, free markets, equity and egalitarianism.

Indeed, historically, democracies in the making did not look different from autocratic or authoritarian states. They employed similar tools of nation building: war, violence, exclusion, exploitation, and oppression. Yet in some western regions the landed aristocracy weakened, a particular type of early industrialization emerged, merchant and commercial classes grew in importance, and tax systems were modified to reflect these changes. This led to the extension of the franchise and the creation of systems of control upon those who wielded power. ${ }^{5}$ Many were tossed aside, and the franchise was not granted to everybody but in comparison to other systems, the demos progressively expanded.

Individual freedom became a very precious and rare feature which grew in importance as democracies consolidated during the twentieth century but the equilibrium between this growing tendency and class privilege continued to be fragile. Political and economic elites, however, understood that democracy could work in their best interests and gained them legitimacy as rulers. The system remains experimental and imperfect to this day. Comparatively, however, it has evolved into a set of individual

\footnotetext{
${ }^{4}$ Ryszard Legutko (2018) The Demos in Democracy: Totalitarian Temptations in Free Societies. Encounter Books, New York.

${ }^{5}$ See for instance the classic work of Moore, Barrington. Origins of Dictatorship and Democracy: Lord and Peasant in the Making of the Modern World. Bacon Press. 1966. For the same question with a focus on Latin America, see Lopez-Alves, Fernando (2000) State Formation and Democracy in Latin America, 1810-1930, Duke University Press. See as well Rokkan, Stein. (2007). State Formation, Nation Building, and Mass Politics in Europe: The Theory of Stein Rokkan. Based on his Collected Works, edited by Peter Flora, Stein Kuhnl, and Derek Urwine. Comparative European Politics Series: Oxford University Press.
} 
rights that has no match in recorded history. ${ }^{6}$ Even if these precepts did not fully materialize in practice, they endured overtime and become an articulated ideology ingrained into the very definition of democracy, with enormous positive consequences for the betterment of those less favored.

\section{Populist Nationalism in Today's Democracies}

Nationalism has never subsided, but in the $21^{\text {st }}$ century has experienced a renascence in combination with populism. ${ }^{7}$ Despite its reputation as an ideology that encourages violence, war, and division it can also offer a positive glue uniting people as collectives. Vicente Cacho $\mathrm{Viu}^{8}$ has claimed that by the end of the nineteenth century and the beginning of the twentieth Catalan nationalism, for example, acted as a positive force that contributed to modernizing Spain and to unify it. ${ }^{9}$ Leah Greenfeld sees nationalism as the needed "spirit" that brought about development and a leap forward toward people's welfare. ${ }^{10}$ She argues that this is like what Max Weber posed in the Protestant Ethics... about the positive influence of religious values in capital accumulation and the cultural revolution that led to individual entrepreneurship. Nationalism, thus, can be a needed and beneficial force that contributes to economic development, democracy, and collective trust. It can also bring about needed resistance against oppressive corporate global forces, empire, dictatorship, or invasion by foreign powers.

Yet the $21^{\text {st }}$ century combination of nationalism with populism, both on the right and on the left, has become a problem for liberal democracy since it questions the very foundations of liberalism and globalization. PN's strength stems from the failure of liberal democracy to keep its promises; in several ways, it represents a rebellion of the "demos". It feeds from greedy politicians, citizens' mistrust, and the consolidation of a new political and financial aristocracy with strong ties to corporate capital, the media, and foreign powers at the core of democracy.

Because the $21^{\text {st }}$ century global system has been characterized by a search for identity and belonging at the national and regional levels, it has added to the power of PN. Even the most enthusiastic cheerleaders of globalization and convergence cannot ignore the irresistible search for the local and the "authentic" as opposed to the bland acceptance of global influence. Other changes in the international system also contribute to strengthen PN. Unlike the liberal order that followed WWII, this system is much more chaotic.

\footnotetext{
${ }^{6}$ Modern Western democracies in Europe and America, at least in paper, conceived their nations along the lines on civic duty, citizenship rights --regardless of race, education, economic status or ethnicity - fair and regular elections, peaceful transitions of power, a free press, and a sense that heterogenous groups within they polity shared the same collective will.

${ }^{7}$ Lopez-Alves and Johnson, op. cit.

${ }^{8}$ Hechter, Michael (2000) Containing Nationalism, Oxford University Press.

${ }^{9}$ Viu, Vicente Cacho (1990) El nacionalismo catalán como factor de modernización, Madrid, Fondo de Cultura Económica

${ }^{10}$ Greenfeld, Leah (2001) The Spirit of Capitalism: Nationalism and Economic Growth, Harvard: University Press
} 
Richard Hass has argued that the global system is "in disarray", and others have shown that globalization creates more uncertainty. ${ }^{11}$ It hosts the highest number of international actors in recorded history, some of them with access to resources far beyond what governments can control. This means that individuals can feel powerless in a world that is out of their control. PN and other like local organizations offer identity and a sense of belonging.

In addition, nationalist reaction against international influence has grown $40 \%$ globality since the late 1990s. No wonder PN has become a major force behind divergence and identity searching everywhere. Conservative right-wing $\mathrm{PN}$, as it materialized under Donald Trump, for instance, transformed a group of people --usually white, conservative, long term residents, and living in rural areas or smaller towns-- into the "real" nation. This PN wishes to rescue a nation that it perceives threatened by the left, identity politics, immigrants, and a liberal party that no longer defend national interests.

As most other conservative manifestations of PN in Europe and elsewhere, it promotes a nativist conception of the collective based upon traditional representations of symbols and history -- the American flag, the Constitution, law and order, the National Anthem, the American dream, American freedom, etc. Trump's version put together a public discourse of "America First" and anti-globalism that resonated with these voters and also with those who wanted to "shake the system" and punish traditional politicians and multinational corporations.

The 2016 election showed that about 75 to 78 million people felt that way. Like their counterparts in Latin America in the early 2000s, many of them were experiencing unemployment, disenfranchisement, and the sentiment that their country had been taken over by others. They did not share in the benefits brought about by globalization, high tech, communications, and the service economy, and demanded more representation. The highly educated, technocrats, and a democratic party that had broken its alliance with the working class, became their enemy.

Other groups rather than whites have historically fought for more representation in America. The long history of African Americans' struggle is well known. In addition, since circa the 1970s, "Latinos", an heterogenous group composed of immigrants from different parts of Latin America with different cultures and political affiliations, organized and constructed a powerful voice as well. Asians soon followed suit. They also encompassed more than 10 different ethnicities and nationalities lumped together in one category. In the $21^{\text {st }}$ century, however, it was the white low middle and working classes that feel disenfranchised and left behind. 
That poor withe citizens felt discriminated against should not have come as a surprise. Nancy Isenberg's book White Trash, published before Trump became President, showed how rural and working-class Americans believed that they have been punished by globalization and forgotten by a political elite dedicated to capture the vote of minority groups. They felt that immigrants, people of color, politicians, and members of the educated elite despised and humiliated them. Their children could not rip the benefits of high-tech jobs and other benefits of globalization. Trump's message found its audience here: "I have visited the laid-off factory workers, and the communities crushed by our horrible and unfair trade deals. These are the forgotten men and women of our country, and they are forgotten, but they will not be forgotten long. These are the people who work hard but no longer have a voice. I am your voice" 12

The conservatives' call for unity under flag and country, however, does not favor consensus. It has become a wedge that separates "patriots" from the rest. And "the rest" are precisely "the other'. Immigrants and refugees are a case in point. Liberals say that immigrants should be given equal rights to natives. Conservatives find that insulting. Leftists and liberals call for open borders and encourage newcomers to keep their original cultures, religions, and customs. PN conservatives believe this to be treasonous. Not to mention access to welfare benefits and a track to citizenship. Thus, the visions of the American nation that these sides support are totally at odds. What has also occurred during this debate, is that immigrants and refugees may purposely refuse to adapt to the home country, provoking the ire of conservatives and the complacency of liberals. ${ }^{13}$

\section{Political Correctness and the Nation}

Left wing PN is not less divisive than its right-wing counterpart. It also encourages a direct connection between people and leaders and wants to create a different version of national identity basically by pointing to the injustices and errors of the past. It separates constituencies along the lines of identity politics. Politically correct liberals seek to gain minority constituencies using the banners of racial, gender, LGBTQIA, and immigrant justice. They also bet on the appeal that this may have for educated white voters, especially young ones. ${ }^{14}$ Despite its original good intentions, political correctness has become an ideology that often encourages reverse discrimination and

\footnotetext{
${ }^{12}$ Cited in John Kenneth White, chapter 12, Lopez-Alves and Johnson, op. cit.

${ }^{13}$ In a very informative book, James Kirchick has shown the unwillingness of middle eastern immigrants to adopt the ways of their host European societies and how the left has helped them to accomplish this goal. See his The End of Europe: Dictators, Demagogues, and the Coming of the Dark Age, Yale, University Press. 2017.

${ }^{14}$ Political correctness is a term coined by leftist organizations of the 1970s and early 1980s. It was meant to have humorous overtones, but it has evolved to mean the strict avoidance of using pejorative or offensive language against disadvantage members of society. It has evolved into an ideology that went from promoting inclusive language in public discourse and the media, to lawsuits against those who did not. Not to speak a politically correct language when addressing co-workers or subordinates both in the public sector and in the corporate world has made life better and restored dignity. enforcement of these rules usually results in reprimands and in damaging evaluations or work performance.
} 
is dismissive of people who do not conform. It has become a culture into itself and in many cases a severe doctrine that requires absolute compliance.

The constituencies of identity politics are no longer united by political ideology but, rather, by race, ethnicity, gender, or sexual preference. Barriers to entry are almost unsurmountable since membership is based upon the physical characteristics of persons. Culture has become a secondary factor. Allowing people to "choose" their identity has been offered as a palliative measure but it has not worked out as expected. Say you select a particular group as your identity, I am white but "feel" Latino or Black. The chosen group, however, makes the final decision and rarely newcomers are accepted. Most within these "communities" see other people who are physically and culturally different from them as persons with whom they cannot have much in common. ${ }^{15}$ Politicians, the media, and academia invariably label these groups "communities" to convey an idea of intimacy and solidarity that supposedly unites members. And yet, these groups remain internally divided.

This vision of the larger nation in which many smaller "nations", theoretically, coexist under one state and have the right to make decisions based upon their own cultural norms, race, religion, and ethnicity, has been historically proven to be unstable. We know what can happen if segregation consolidates in societies in which different races, ethnicities, and religions live under the same state. The period prior to WWI is a clear example. ${ }^{16}$

The aftermath of that war and the Europe that ended in WWII provides plenty of evidence as well. Roshwald, among many others, has offered supportive data showing what can happen if a large political unit, democracy in this case, is fractured due to cultural and ethnic conflict. ${ }^{17}$ Are we at that point today? Negative, but democracies encouraging radical identity politics are playing a dangerous game that can fracture the idea of a larger collective.

At bottom, this version of a nation divided into identities, races, and cultural preferences, questions one of the most important accomplishments of democracy: the creation of multicultural, multiracial, and multiethnic collectives that can share a common national vision both collective and individually of its future, despite of diversity. If the common vision disappears, unity weakens. True enough, liberals keep

\footnotetext{
15 "Community" by now one of the most used and misused labels in American political discourse. Community means "a group of people with a common characteristic or interest-including professional interests-- living together within a larger society". By this definition, most of these constituencies do not actually qualify.

${ }^{16}$ See, for instance, the excellent book by Tuchman, Barbara W. (1966) The Proud Tower: A Portrait of the World Before the War, 1890-1914, New York, Ballantine Books. See also Hastings, Marx (2013) Catastrophe 1914: Europe Goes to War, New York, Alfred A. Knopf, Random House, and the wonderful account by McMillan, Margaret (2013) The War That Ended Peace: The Road to 1914, Alfred A. Knopf, Random House

${ }^{17}$ Roshwald, Aviel ((2001): Ethnic Nationalism \& the Fall of Empires. Central Europe, Russia \& the Middle East, 1914-1923. London: Routledge.
} 
calling for unity. Yet their electoral strategies work in the opposite direction. Diversity can be celebrated if it does not totally unglue the whole. Democracy can be at peril if people believe that government actions and policies must be tailored to fit their own cultural, racial, and political needs. The nation vanishes, and the larger collective becomes fragmented and compartmentalized.

Dialogue, an essential feature of democracy has thus become increasingly difficult. Liberal members of the US Congress have referred to their political opponents as people that "should be reeducated and decoded" to be admitted into American society. Republicans argue that liberals are plotting to transform democracy into a socialist and communist state. The left wing of the democrats has accused the opposition of trying to install a Nazi regime in America and reestablish a sort of postcolonial slavery. Republicans believe that democrats in power are ruining America and selling it to foreign powers, especially China. The first executive orders signed by Joe Biden after taking office have confirmed conservatives' worst fears. ${ }^{18}$

The left aims at rewriting national history and in many US universities, for instance, long established courses on Western Civilization or European History have been replaced by classes depicting the pitfalls of European colonialism, white racism, the failures of western democracy or the exploitation of minorities.

Sympathetic versions of the history of other regions of the world, especially Africa, the Middle East, Southeast Asia, and Latin America have replaced them.

While all these topics merit discussion and teaching, the elimination of any reflection about the history of the west -except those inspired by radical history and revisionist versions-creates the false belief that any other culture seems better, warmer, less prone to exploiting others, and guilt free. Abundant in high school and college curricula are courses that connect democracy with colonialism, exploitation, and empire. Curiously enough, China and Russia, real empires still in expansion, are not usually targeted.

American liberal democracy is so divided that many citizens have placed their hopes in the hands of public bureaucrats and managers. Institutions, they believe, are strong enough to fight off centralization tendencies and the enemies of democracy. Are American institutions strong and autonomous enough?

So far, US institutions have worked, yet with great difficulties, as has been the case with Congress, the Senate and even the Supreme Court. If political elites continue to be divided over their different versions of the American nation the US may experience

\footnotetext{
${ }^{18}$ Immediate amnesty for the 20,000.000 illegal immigrants who reside in the US; 85,000.000 H1 Visas a year for skilled workers -usually engineers from India and China-- that would satisfy the labor needs of Silicone Valley and big tech monopolies; a substantial increase in the number of refugees visas that the country would grant, going from 15,000 under Trump to 35,000 under Biden, and the promise of a reverse in US foreign policy toward China and Mexico
} 
what we have seen elsewhere: divisions at the top provoke a trickle-down effect that eventually reaches into middle and lower levels of public management. Divisions continue to grow despite the results of the 2020 election.

Lastly, to the question of why PN has found such a strong place in American politics the answer is that this is not the first time that PN channels popular discontent. The populism of the 1820s and 1830s under President Jackson, the so-called progressive Jacksonian democracy, first populist government not only in America but in the world, is an example. It had a working class and rural poor component. Many politicians thereafter were described as populists: George Wallace (Alabama's Governor in the 1960s and a candidate for the presidency) was called a populist and a demagogue, and he accepted the first charge gladly. President George W. Bush was said to have a populist panache when communicating with the "people" and addressing audiences using direct and straight forward language. The frank style of President Harry Truman was not openly labeled populist, but he had, as both his foes and friends remarked, been trained as a politician in the populist and clientelist political atmosphere of his native Independence, Missouri.

Bill Clinton and Ronald Reagan, very different kinds of leaders with dissimilar visions, share a flair for populism when addressing his parties and cultivating direct linkages with their followers. Furthermore, they both talked, like Trump, of a greater America, of rescuing traditions that were under threat, not to mention the need to defend our national values against any possible foe. These were phrases often used by Donald Trump. Steve Bannon, Chief White House strategist during the early years of the Trump's presidency, often claimed a direct connection to the populism of the $1820 \mathrm{~s}$ and 30s under President Jackson.

What is different today is that the nationalism of this PN possesses a racial and ethnic component. Ideological disagreements can be negotiated. Differences in ethnicity, race, sexual preferences, and gender are less so.

Democracies have also complacently ignored other powerful enemy that can crush its principles and undermine its philosophical principles. I am talking about democracies' contribution to growing social and economic inequality at a global scale. In the $21^{\text {st }}$ century, the most powerful global elite in human history, has already formed a different kind of aristocracy. And this has occurred under democracy's watch and with its blessing.

\section{Economic Inequality and The Less Than One Percent.}

In 1941, George Orwell wrote the prologue of a book with which he did not agree but that became a classic, The Managerial Revolution, by James Burnham. 
He summarizes Burnham's argument thus:

"Capitalism is disappearing, but Socialism is not replacing it. What is now arising is a new kind of planned, centralized society which will be neither capitalistic nor democratic. The rulers of this society ...will be business executives, technicians, bureaucrats, and soldiers...the managers. This people will eliminate the old capitalist class, crush the working class, and so organize society that all power and economic privilege remain in their own hands.... Internally, each society will be hierarchical, with an aristocracy of talent at the top and a mass of semi-slaves at the bottom.." ${ }^{19}$

Socialism, Burnham argued, will never dominate the world - this was the kind of socialism, by the way, that prior to 1930 connoted political democracy, social equality, freedom, and internationalism. Socialism emerged as a corrector to autocracy. Socialists zeroed on the tensions between the demos of democracy and liberalism. In the 1990s, socialists and leftists pointed to similar contradictions between the principles of democracy and neo-liberalism. These tensions reveal the deterioration of the social contract that since the eighteenth-century has sustained liberal democracy. Patrick Deneen has indeed authoritatively argued that liberalism is to blame for the aggravated conflict that in the $21^{\text {st }}$ century is unfolding between the "demos" and the liberal creed, with negative consequences for the future of the system. ${ }^{20}$

It seems that we are facing today a very similar situation to the one described by Burnham in 1941. Very few, however, are paying attention to this unfolding drama, and those who do have been tossed aside or simply ignored because their writings and opinions are no longer trendy or cool enough to provoke public debate. The focus of $21^{\text {st }}$ century public discourse is elsewhere. Race relations, minority rights, the plea if refugees, and racial justice have taken most academic and journalistic attention. Growing economic and social inequality in the US or the EU, however, have conveniently become secondary issues. While all these matters need attention, problems of wealth distribution are much harder to fix because they do not depend on public policy alone. Thus, governments have focused on agendas that, despite expected resistance, are easier to push forward, like women rights, racial justice, LGBT rights, gay marriage, etc.

To impulse real structural change and wealth distribution is a different matter. Partiescan lose the support of wealthy sponsors, and international financial elites can place those governments at the bottom of their priority lists. Corporate capital and most media outlets, not to mention important sectors of the intelligentsia, have gladly encouraged a focus on other issues to the detriment of one of the most important problems of 21st century democracy: economic inequality and the increasing stratification of society. Contrary to expectations, the dissolution of the so called liberal international

\footnotetext{
${ }^{19}$ James Burnham (1941) The Managerial Revolution: What is Happening in the World, John Day Company

${ }^{20}$ Why Liberalism Failed, (2018) Yale University Press.
} 
order that emerged after WWII, did not bring about the continuous growth of the middle classes and increasing individual opportunity for the poor, two of the major foundations of liberal democracy. Democratization seems to have halted at the doors of the $21^{\text {st }}$ century.

After the dissolution of the Soviet Union, we were bombarded by books and scholarly pieces discussing the inevitability of democratization. There was, it was argued, a first "wave" a second one, and, as Samuel Huntington claimed, even a third. Autocracies and dictatorships were becoming a thing of the past. At least at the core of the global system (the EU and the United States), liberal democracy seemed to forever reign. Not to mention "the end of history" as we knew it, as Fukuyama smartly argued. There is, however, nothing inevitable about the life spam of any regime in human history, and democracy is no exception. Democracy is the demos' aspirations to equity, egalitarianism, and self-rule. These aspirations do not fit in the $21^{\text {st }}$ century postindustrial economy. Rather, a new form of aristocracy that concentrates wealth and privilege in fewer hands has tightened its grip on the global economy and the institutions of democracy. This small group is today the most important decision maker, nationally and internationally.

The share of global wealth by a privilege $0.1 \%$ of the population (this percentage is lower and is getting even smaller as I write) has increased from $7 \%$ in 1978 to $29 \%$ of global wealth at the present time. This is an astonishing figure that has no precedent in recorded history. And it seems unstoppable. By 2030 we expect less than $1 \%$ of the population to concentrate two thirds of the world's wealth. Elected political leaders are increasingly dependent upon, and aspiring members of, this elite. This is true of liberals, leftists, and conservatives alike, worldwide. Despite the efforts of small donner campaigning in the US and the EU, and some challenging calls from people like senator Bernie Sanders, big capital vastly influences party agendas.

Democracies are afflicted by the declining reputation of their elected representatives. In the United States, $76 \%$ of citizens in 2018 believed that politicians did not really pay attention to their needs and remained disconnected from the necessities of those who voted for them. In Latin American democracies, $79 \%$ of interviewees in 2019 expressed the opinion that the Catholic Church, discredited and all, was more trustable than politicians. In the European Union, the prestige of Belgium has steadily decreased and except for Germany the approval rate of the Italian, Spanish, British, French, and Portuguese governments reached a bare 30\% average in 2019.

Neo-medievalist theories have convincingly argued that we are globally reproducing the system that reigned the European world during the so-called Middle or Dark Ages. 
That period in European history ${ }^{21}$ would resemble our own times in several respects: the distribution of wealth, the concentration of political power, and the creation of an underclass of poor and low-income laborers who play a similar role than the peasantry did from the year 800 to the 1500s. The demise of the middle classes, groups that enjoyed approximately 60 years of prosperity after WWII, is approaching. As Kotkin argues, the middle classes would fare even worse than Yeoman did in the Middle Ages, since their access to land and property is quite limited and their access to financial capital rapidly diminishing.

It is sobering to think that in 1945 the 1 top \% of Americans perceived $4.9 \%$ of total income growth. Today, the combined wealth of 400 American families exceeds the total capital of $185,000.000$ of their fellow citizens. Democracies have become more stratified and offer decreasing chances of social and economic mobility. Big capital is asphyxiating smaller business, a sign that capitalism based upon individual entrepreneurship and community initiative, the one that fascinated Alexis de Tocqueville in his visit to the young nation, is losing its inhouse dynamo. In 1966, Baran and Sweezy warned that the concentration of capital in fewer hands was an indicator of rising inequality and the nemesis of competitive capitalism and entrepreneurship, the kind that defined America and made it, for most immigrants, the "land of opportunity". Monopoly capital, they argued, was the future of the United States. ${ }^{22}$ Their warning is today a present reality of democracy in America and elsewhere.

In the $21^{\text {st }}$ century the monopolization of capital, industrial and financial, has become a worse real and present danger to equality and equity than those in the 1960s and 1970 s could have predicted. This is not the same kind of monopoly capital that Baran and Sweezy or Maurice Dobbs spotted during those decades. At that time, smaller capital sought to expand through mergers which started a process by which capital became more monopolistic. Still, wealth could be made outside these large monopolies and individual inventors of new technologies could make contributions outside that framework.

The most important industries of the 4 rth industrial revolution are part of big monopolies almost from the start. Al, robotics, autonomous vehicles, 3D printing, nanotechnology, biotechnology, energy storage, automation, and quantum computing, to name only a few, are owned and sponsored by multinational big capital outlets. Giant service industries like Amazon ${ }^{23}$ are already venturing in space exploration and partnering with surveillance high-tech companies producing radars and face recognition. It is believed that private capital, rather than governments, will be leading space traveling and mining ventures in nearby planets, starting with Mars.

\footnotetext{
${ }^{21}$ Among others, see Joel Kotkin (2020) The Coming of Neo Feudalism: A Warning to the Global Middle Class. Encounter Books, New York.

${ }^{22}$ Baran and Sweezy, Monopoly Capital: An Essay on the American Economic and Social Order, 1966, Monthly Review Press.

${ }^{23}$ See Klaus Schwab, The Fourth Industrial Revolution, (2016) World Economic Forum,
} 
As many other revolutions, the $4^{\text {th }}$ has provoked intense criticism from intellectuals, conspiracy theorists, and even governments in the less developed world. Yet by now a very tiny minority of the very rich is almost in total control of this revolution and the wealth it can create. Prestigious institutions of higher learning, usually private, are becoming elitist partners in these transformations. They offer their graduates membership into a select group of professionals who hold the right credentials and connections. In many ways, this exclusive professional/technocratic elite resembles that of the Middle Ages. From the $11^{\text {th }}$ to the $14^{\text {th }}$ centuries, only those with the correct connections and the blessing of the right institution were able to craft the dominant discourse and accepted notions of success or failure.

This revolution is reshaping production, consumption, and transportation but unlike prior technological revolutions small entrepreneurs or inventors are not its leading figures. Startups are quickly engulfed into preexisting giants. Social media is the major vehicle of communication especially among the younger. And very few companies own it. Google controls $80 \%$ of social media traffic. Facebook has engulfed Instagram, WhatsApp, Oculus, and other startups, sometimes before they come into the open market.

Every other week, Google buys off a smaller company; by 2020 it controlled 240 new companies and it continues to grow. Amazon monopolizes more than $70 \%$ of book sales in America and is continually expanding into new markets including real state, while Apple manufactures more than $95 \%$ of software for mobiles. Antitrust actions, a very telling variable, has reached its lowest point in the US, falling $65 \%$ since the early 1980s; $90 \%$ or more of advertisement is controlled by Google.

Social media techs and communication leviathans provide the illusion that our opinions and input matter in the big scheme of things. Yet popular opinion only matter when it increases market profits or when it brings to the attention of Google, Twitter, Instagram, Facebook, or Amazon threatening political positions that need to be manipulated or suppress. This concentration of tech power and control says a lot about the future of democracy.

Manifestations of inconformity and dissent of course exist, this is part of being a democracy. And yet they are handled down under a veneer of political correctness, civility, and the illusion of freedom. This is not totally new. Yet, in the past, elites did not possess the powerful tools of mass surveillance and public opinion control that $21^{\text {st }}$ century technology provides. China is a good case in point. A small elite has been able to manipulate public opinion and crash the opposition using severe repression but, above all, high tech surveillance and hacking. In addition, unlike most of the west, the appealing idea of a manifest destiny uniting all Chinese who share the same ethnicity contributes to unity. 


\section{The Declining Appeal of Democracy}

While in the past other countries looked at workers in the EU or the US as examples of social mobility and opportunity, this image has started to dwindle. Workers in developed democracies, like those in the less developed world, have now been reduced to low paid jobs that cannot cope with inflation. Instead of savings, they hold increasing personal debt. Low skill working classes in these democracies are now a part of a new global proletariat, in the genuine sense of the word.

The probabilities of working-class citizens to own a home or land has become an untenable dream. Most of them have now become eternal tenants. Those who own a home and manage to stay afloat, have seen their income diminish due to inflation and salary depreciation. Despite the recovery from the 2018 real estate crisis, foreclosures in the US are $17 \%$ higher than in 1990 . Some have argued that postindustrial capital diminishes the income of the working classes by blocking their access to what has been the only opportunity to acquire some capital and generate some savings: home or land ownership. ${ }^{24}$ Real estate investment had traditionally been their way to fight inflation and secure heritable wealth.

In the USA, 100 large landowners have increased their control of the country's land in $50 \%$ from 2007 to the present day. At the time of this writing, they possess about 45.2 million acres. The land thirst has also affected Europe; in Britain, less than 1\% of the population owns half of all land. Corporate capital has become the largest landholder in the United States and by far the largest owner of rental property. A similar situation is taking place in continental Europe, Latin America, Southeast Asia, and Africa, where large global corporations, increasingly from China, are pursuing ambitious land grabbing strategies focusing on mining, water, and agriculture that, in time, will further diminish small household ownership.

Would there be a trickle-down effect connected to the $4^{\text {th }}$ revolution? Opinions differ but one thing is for sure: the working classes will not, for a long time to come, share in these benefits. Retraining programs and structural changes in education are required. Especially in the US, however, public education policies and curricula are not designed toward that end. Expensive private universities, on the other hand, are making visible progress in offering some of that training but it is not enough. China is much ahead of the US in retraining their labor force and in the teaching of math and calculus, graduating 5 times more engineers than the US yearly.

The capacity of savings of US citizens adds to a dismal picture. In the late 1970 s the American middle class saved about 7.5 percent of their income. For skilled workers, the rate was $5.5 \%$. Nonskilled labor still managed to save $2.7 \%$ of their income.

${ }^{24}$ See for instance Thomas Piketty, Capital in the 21st Century. Harvard University Press, 2012. 
By 2019, according to official figures, ---due to covid19 figures for 2020 do not count-- the capacity of savings of both the middle and working classes in America had go down to $0.1 \%$, and this is a generous figure since we do not have enough information about nonskilled immigrant working classes, usually undocumented, and that remit much of their income to their home countries. Credit card debt has gone up $45 \%$ since 2000 , which indicates not only the increasing power of financial capital but also the decreasing purchasing capacity of the dollar.

Are social European democracies more equitable and therefore stronger, more attune to the needs of the demos? Not really. In Finland, for instance, stock ownership is more concentrated than in the US. In Sweden and Switzerland, the concentration of wealth in a few hands is growing. Citizens do not to fare much better, even though they receive more benefits from their governments.

One must ask if this concentration of wealth is a syndrome of corrupt capitalism or a sign of the decline of the liberal West altogether. Liberal democracy has learned to live with these antidemocratic trends. The question is for how long, and weather more economic inequality can be offset by illusions of progress under a more centralized system regulated by the less than $0,1 \%$.

No wonder pessimism has become endemic in democracies across the world. In 2007 a study found that people living in democracies across Latin America, Australia, and New Zealand, thought that the future of their countries was uncertain and that their children would be worse off than they were..$^{25}$ The Pew Research Center has recently reported that more than half Europeans feel likewise. In France, the pessimists outnumbered the rest by 7 to 1 . In the US, the figure was $57 \%$, in Australia 64\%, and in Canada $67 \%$. In sum, the study revealed that $56 \%$ of citizens in developed democracies believed that their children will not be better off than themselves.

The future of liberal democracy depends on the resolution of these and other problems. Some of them are not solvable purely at the national level and depend, rather, on a chaotic global scenario that no actor on its own can control.

Democracies are proud, and they should be, to stand alone as the only regimes on earth where free public opinion is allowed, and self-censure is common. Unlike in the past, however, this wonderful achievement does not seem to gain liberal democracy much recognition.

The popularity of China in some regions has diminished the international influence of the US and he EU. China is depicted as being much more successful. It has cultivated an image as a champion of globalization and a helping hand for countries in need of development and investment. Imperialism with a smile, as practiced by the Chinese, 
seemed to have worked wonders with political leaders in Africa and, increasingly, in Latin America. China's investment has tripled in Africa since the early 2000s and it has doubled in Latin America. In Asia, a region that the CCP believes has the right to dominate, Chinese investment and influence seems unstoppable. ${ }^{26}$ When financial or industrial dependence does not work, military and police intervention do, as is the case with Hong Kong and the South China sea. Some authors have argued that the superpower, despite the Hong Kong situation and nationalist resistance from other quarters like Japan and South Korea, is now controlling most of the region finances and heavy industry. ${ }^{27}$

The fact that the selection of Chinese leaders "takes place almost entirely behind closed doors", depends on negotiation among top leaders and "a popularity contest among the $\mathbf{2 0 0}$ members of the communist party that comprise the central committee" does not seem to substantially damage China's economic expansion..$^{28}$ Indeed, sometimes the technocratic despotism of China is even admired. ${ }^{29}$ Especially those adhering to different forms of leftist and right wing PN, have opened the door to Chinese influence, economically and politically. The "Chinese model" is many times regarded as a viable and more effective solution to their problems. Not to mention that it would guarantee that these elites would perpetuate themselves in power. ${ }^{30}$

Secrecy and the control of the media in China and to some extend in Russia are curiously enough playing in their favor. Unlike the scarce knowledge that the public can gather of the behind the curtain's domestic politics of these superpowers, the political drama of democracies has become the showcase of all media outlets. Given their openness and more humanitarian attitude toward foreigners, democracies face immigration and refugee crises unknown to the other two superpowers. Their immigration policies are rigid and exclusionary. In the case of China, citizenship is granted on the exclusive bases of having the right ethnicity, if at all. Dissidence of course endures and their repressive policies are not a secret. ${ }^{31}$ But nobody doubts that China is a model to reckon with.

\footnotetext{
${ }^{26}$ Tom Miller, op. cit. Introduction.

${ }^{27}$ Chan, Gordon. The Growing Power of China. Bentham Books, New York, 2020.

${ }^{28}$ Quoted from Elizabeth C. Economy (2018) The Third Revolution: Xi Jinping and the New Chinese State, Oxford University Press, pp 21-25.

${ }^{29}$ Lopez-Alves, op. cit. (2019), pp 12-15.

${ }^{30}$ Lopez-Alves, Fernando. 2019. “The United States, China, and Democracy's Declining Appeal”. Current History (Historia Actual) November.

${ }^{31}$ Jeffrey N. Wasserstrom, (2010) China in the 21st Century: What Everyone Needs to Know. Oxford, University Press
} 


\section{Conclusions}

Democracies are now living in a different world where their moral and institutional attractiveness is losing grounds, domestically and internationally. Racial problems, political quarrels and theatrics, disconnection between the executive and Congress, and squabbles between EU members and Brussels, has all been openly publicized. This is part of living in an open society. And yet, oddly enough, China, doing the opposite, seems to be asserting her position not only economically but also politically in the global arena. Russia is something else altogether. Her land grabbing strategies aimed at regaining control of some of the former Soviet Socialist Republics and their active and open military participation in Syria and other regions, has not helped Putin Russia's reputation. The country has followed old fashion strategies of aggrandizement that has not positively resonated globally. China, however, has done otherwise, and the USA has continued to do what has always done, that is, increasing its military power and trying to still control the world financial system. Of the three, China seems to be winning in terms of pursuing a coherent, soft spoken, but ruthless strategy.

At this point, democracies are having a hard time competing with China economically. If they were to really join forces against the Asian giant, they would still come ahead in that race but perhaps for a short time. Militarily, the US still has still the upper hand. Democracies in the EU however do not, despite the revival of NATO but backed by the US they are a mighty enemy. Russia has what has traditionally possessed, a strong membership in the nuclear club. Thus, in terms of military capacities, the lines are clearly marked.

Yet foreign policy is more than military might, and China's approach seems to be paying off. It has been designed for the long term and is quite consistent. Once the CCP takes a course of action there are neither bureaucratic bumps along the road nor political opposition that could stop it. This gives China a huge advantage over any liberal democracy on earth. Democracies' foreign policy heavily depends on who sits in the presidential palace, parliament, or Congress. One of the only consistent characteristics of US foreign policy has been its support of neoliberalism. ---even during the anti-global stance of the Trump era-- and this has gained the country a dubious reputation. While neoliberalism is not necessarily tied to the philosophical tenants of democracy, the association is strong enough that the two are usually seen as one and the same.

China's economic might has posed the question of whether this would be a better system than liberal democracy. The answer is no. The 1\% upper Chinese class concentrates $25 \%$ of the country's wealth, and this trend continues to grow. The number of Chinese billionaires is matching that of the US and will surpass the American rich by 2030 . At the current rate of growth -usually exaggerated by the CCP-by the 
next decade the concentration of wealth in China will match that of the west but under more restrictive political and social conditions. Like in liberal democracies, the very opulent have consolidated into a new aristocracy backed by the CCP that is constantly expanding its global ties. ${ }^{32}$

Our next question is whether these two very different superpowers, the US and China, share certain characteristics. Shockingly enough, there is a likeness. Both are being ruled by an alliance of entitled political elites and billionaires. The concentration of wealth in both is similar. China is a highly stratified society. The US, or the EU are not, but there are robust indicators to argue that liberal democracies may be going in a similar direction.

Institutions of course are quite different. At the same time, liberal democracies are not decentralizing power but rather concentrating it into fewer hands. And its political elite openly favors nepotism, friends, and supportive networks, features that should have decreased in importance as democracies reached the $21^{\text {st }}$ century. If you add to the comparison the relative decreasing power of the unskilled working class, these very different regimes look like distant cousins.

What can liberal democracy do to be sustainable? Democracies have indeed become more centralized, and under the influence of the 4rth revolution and its enormous concentration of wealth and power that trend seems almost inevitable. This could temporarily work in the short term, but it would turn democracy into something different from its original inspiration.

As an alternative, democratic regimes could decrease their dependence upon corporate lobbies, which would totally change electoral laws and the very meaning of elections. Yet in this scenario liberal democracy would have to find a different and more autonomous way to function, away from party donners and tax write offs. It would also stir staunch opposition by private capital that would undermine the very core of liberalism.

Finally, in an ideal world, political elites could abandon PN ideology and identity politics in the hopes of reconstructing the nation as a collective united by common goals and faith in a better future despite diversity. That would also mean to restore the moral reputation of elected representatives and gain back the respect of voters, something that started to fade away shortly after the 1950s at a global scale. This does not necessarily mean that those who wish to reinstate the trust of the demos, if this ever fully existed, must strictly abide by $18^{\text {th }}$ century precepts of the French Revolution or the guidelines of the American founding fathers. It would mean, rather, the construction of a collective political will aiming at assembling a better system

32 On Chinese expansion in Asia and the world, see Tom Miller, China's Asian Dream: Empire Building Along the New Silk Road, (2017), London, Zed Books. 
almost from scratch, while respecting the historical processes and achievements that brought this unique arrangement in human history to life.

\section{Bibliography}

1. Acemoglu, Daron and James A. Robinson, (2012) Why Nations Fail: The Origins of Power, Prosperity and Poverty. New York. Random House

2. Armstrong, John A. (1973) The European Administrative Elite, Princeton, University Press

3. Bancroft, Timothy and Mark Hewitson ed. (2006). What is a Nation? Europe 1789-1914. Oxford University Press.

4. Baran and Sweezy, Monopoly Capital: An Essay on the American Economic and Social Order, 1966, Monthly Review Press.

5. James Burnham (1941) The Managerial Revolution: What is Happening in the World, John Day Company

6. Patrick Deneen, (2018) Why Liberalism Failed, Yale University Press.

7. Elizabeth C. Economy (2018) The Third Revolution: Xi Jinping and the New Chinese State, Oxford University Press.

8. Ferrarotti, F. (2021). Are the United States still the "God's Country»?. Academicus International Scientific Journal, 12(23), 9-20.

9. Greenfeld, Leah (2001) The Spirit of Capitalism: Nationalism and Economic Growth, Harvard: University Press

10. Hastings, Marx (2013) Catastrophe 1914: Europe Goes to War, New York, Alfred A. Knopf, Random House.

11. Hechter, Michael (2000) Containing Nationalism, Oxford University Press.

12. Kotkin, Joel (2020) The Coming of Neo Feudalism: A Warning to the Global Middle Class. Encounter Books, New York

13. Kirchick, James (2017) The End of Europe: Dictators, Demagogues, and the Coming of the Dark Age, Yale, University Press.

14. Schwab, Klaus The Fourth Industrial Revolution, (2016) World Economic Forum.

15. Ryszard Legutko (2018) The Demos in Democracy: Totalitarian Temptations in Free Societies. Encounter Books, New York.

16. Lopez-Alves and Johnson, Globalization and Uncertainty, (2007). New York, Routledge.

17. Lopez-Alves Fernando and Johnson Diane (2018) Populist Nationalism in Europe and the Americas, London: Routledge. 
18. Lopez-Alves, Fernando. 2019. "The United States, China, and Democracy's Declining Appeal". Current History (Historia Actual) November.

19. Lopez-Alves, Fernando (2000) Societies with No Future (Sociedades sin Destino) Sudamericana Editors, Buenos Aires.

20. Lopez-Alves, Fernando (2000) State Formation and Democracy in Latin America, 1810-1930, Duke University Press.

21. Miller, Tom (2017) China's Asian Dream: Empire Building Along the New Silk Road, London, Zed Books.

22. McMillan, Margaret (2013) The War That Ended Peace: The Road to 1914, Alfred A. Knopf, Random House.

23. Moore, Barrington (1966). Origins of Dictatorship and Democracy: Lord and Peasant in the Making of the Modern World. Bacon Press.

24. Piketty, Thomas (2012), Capital in the $21^{\text {st }}$ Century. Harvard University Press.

25. Rokkan, Stein. (2007). State Formation, Nation Building, and Mass Politics in Europe: The Theory of Stein Rokkan. Based on his Collected Works, edited by

26. Peter Flora, Stein Kuhnl, and Derek Urwine. Comparative European Politics Series, Oxford University Press.

27. Tyriakian, Edward \& Ronald Rogowski (1985): eds. New Nationalisms of the Developed West. London: Allen \& Unwin.

28. Rich, Norman. (1997). The Age of Nationalism and Reform. Norton \& Company, New York.

29. Roshwald, Aviel (2001): Ethnic Nationalism \& the Fall of Empires. Central Europe, Russia \& the Middle East, 1914-1923. London: Routledge.

30. Rodrik, Dani. (2011) The Globalization Paradox: Democracy and the Future of The World Economy. Norton \& Company, New York and London

31. Todd, Emmanuel (2002) After the Empire: The Breakdown of the American Order. New York, Columbia University Press.

32. Tocqueville, Alexis (1997). Democracy in America, Yale University Press. From the1899 Henry Reeve Translation, revised and corrected.

33. Tuchman, Barbara W. (1966) The Proud Tower: A Portrait of the World Before the War, 1890-1914, New York, Ballantine Books.

34. Viu, Vicente Cacho (1990) Elnacionalismo catalán comofactor demodernización, Madrid, Fondo de Cultura Económica

35. Jeffrey N. Wasserstrom, (2010) China in the $21^{\text {st }}$ Century: What Everyone Needs to Know. Oxford, University Press

36. Weber, Max. (2002) The Protestant Ethics and the "Spirit" of Capitalism and Other Writings, Penguin Classics. 